\title{
A study on customer satisfaction on debit cards: The case of Vietnam
}

\author{
Thi Hoai Linh Truonga ${ }^{a}$ Hong Mai Phan ${ }^{a}$ and Manh Dung Tran ${ }^{a^{*}}$
}

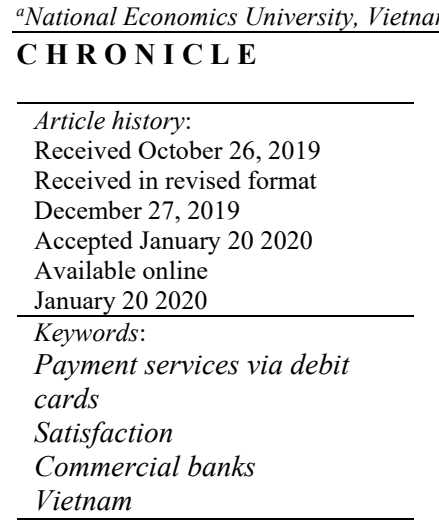

\begin{abstract}
A B S T R A C T
This research is conducted to examine the determinants of customer satisfaction in using debit cards issued by the Vietnam commercial banks (CB). By applying the exploratory factor analysis (EFA), logistic regression and linear regression on a dataset of 428 customers, we find that the features and price of products were the key determinants influencing the frequency of using debit cards. However, the impact of each determinant is heterogeneous among different groups of customers. Product price and features are more likely to influence the users using debit cards to purchase goods or services in stores or online than customers working for the public agencies or frequently using non-cash payment for high-valued transaction.
\end{abstract}

(C) 2020 by the authors; license Growing Science, Canada.

\section{Introduction}

This study is conducted to meet two theoretical and practical needs. First, despite the rapid growth of payment services via debit cards offered by Vietnamese commercial banks, the quality of these services does not meet the clients' expectation. Recently, the number of complaints and inconvenience to customers about debit card services tend to increase. This has resulted in breaking customer loyalty and then switch service providers. Customer dissatisfaction may arise from the shortage and uneven allocation of point of sales (POS), high fee, inadequate and unprofessional customer services (Truong \& Phan, 2017; Oliver, 1980). In fact, debit cards are mainly utilized for money withdrawal rather than online, POS or ATM payments. According to the World Bank, Vietnam has the lowest rate of non-cash transactions in the region at $4.9 \%$ in comparison with $26.1 \%, 59.7 \%$ and $89.0 \%$ in China, Thailand and Malaysia, respectively. Furthermore, customer dissatisfaction and frequent switch on card providers lead to a large number of inactive cards and low card payment turnover. A report by Ernst \& Young in 2014 showed that $65 \%$ of Vietnamese customers were willing to change financial service providers. Although ATMs have accounted for more than $90 \%$ of total bank-issued cards, there have been only 77 million active cards, along with 55 million unused cards. This situation makes bank hardly increase their card payment turnover and suffer more costs to keep track and maintain cash transactions at

* Corresponding author

E-mail address: manhdung@ktpt.edu.vn (M. D. Tran)

C 2020 by the authors; licensee Growing Science. doi: $10.5267 /$ j.uscm.2020.1.003 
ATMs. Due to the significant importance of non-interest revenue to bank efficiency (Nguyen, 2017), Vietnamese commercial banks must continue to aim to increase the popularity of card payment and limit cash transaction in the economy.

Second, previous studies have demonstrated the positive relationship between service quality and customer satisfaction (for example Tran \& Bui 2013, Tran \& Pham 2013, Chu 2014). Generally, earlier studies have considered quality in banking services as "how well the service delivered meets customers' needs". To measure customer satisfaction as well as the linking quality, satisfaction and loyalty in banking services, they either applied the original models of service quality or adjusted some of dimensions of those models in the context of Vietnam. Yet, their findings have contributed to rather than providing implications for banks to make final service decision because data concerning customer's assessment was not completely mined by those researches.

This research focuses on answering the following questions: (i) What are the drivers behind the customer satisfaction and dissatisfaction with debit card services? (ii) How do these determinants affect the choice and usage of debit card holders among different groups? In order to address the questions, we apply another scale to measure service quality which was more familiar with banking services than other scales. We rely on the primary data that was collected from interviewing a survey sample of 428 customers residing in Hanoi-the capital of Vietnam. Thus, findings discovered from analysis are more thorough than that of other researches.

\section{Literature review}

Service quality has been defined obviously by different authors. For example, Olivier (1993), Zeitham (1988) define service quality as a global judgment relating to the superiority of the service provided over customer expectations. Specifically, service quality is referred to as the difference between customer expectations of "what they want" and their perceptions of "what they get" (Brown \& Swartz, 1989; Parasuraman et al., 1985, 1988; Teas, 1993). Based on varied conceptualizations, alternative scales have been proposed for service quality measurement. For instance, Lehtinen \& Lehtinen (1982) highlight that the quality of service as perceived by customers has two dimensions including (i) process of service act (i.e., the manner in which service is delivered) and (ii) the outcome of service act (i.e., what the customers receive from the service).

On the other hand, service providers should demonstrate the ability to deliver and exceed customer expectations not only with how they deliver the services (functional quality), but also with what they deliver (technical quality) and these quality categories may influence customers' image of the service providers (Gronroos, 1984, 2001). Parasuraman $(1985,1988)$ emphasize that there are five dimensions used to evaluate service quality, including (i) Tangibles (representing physical facilities, equipment, and appearance of personnel), (ii) Reliability (representing ability to perform the promised service dependably and accurately), (iii) Responsiveness (representing the willingness to help customers and provide prompt service, (iv) Assurance (representing the knowledge and courtesy of employees and they ability to inspire trust and confidence, and (v) Empathy (representing caring, individualized attention the firm provide its customers).

For measuring the quality of electronic payment service conducted by banks, Humphrey et al. (1996) used four dimensions including output price, infrastructure, safety and financial strength of banks. Using research simple of banks in 14 developing countries, the authors find that banks should be interested in price policies (including fee and interest rates), infrastructure investment (in POS, ATM, etc.) in order to improve their electronic payment services. In later years, Boeschoten (1998), Humphrey et al. (2001) add dimensions of Transaction features, including transaction process, transaction time length and the interaction between bank officers and their customers, particularly in dealing with customer's complaints about banking services. A study on electronic banking by Baskar \& Ramesh (2010) in India finds that the online customer service quality, online information system quality and banking service product quality significantly and positively influence the customer 
satisfaction. Parasuraman et al. (1994) illustrate the need of customer expectation as measured by a comparative standard to evaluate service quality. The aim of increasing service quality is to enhance customer's perceptions in line with their expectations, then eventually to strengthen customer satisfaction. Moreover, this was approved to promote customers repeat patronage (Dick \& Basu, 1994). They describe loyalty as the strength of the relationship between a customer's relative attitude and repeat patronage and found out four following categories of loyalty due to above relationship. Service providers should pay attention to the group of spurious - loyalty customers who are less likely to rebuy the service in the case of their willingness to seek better services that exceed their inertia (Gounaris \& Stathakopoulos, 2004). Thus, it is necessary to meet most of customer expectations rather than their current perceptions in order to make them to consistently repeat their repurchasing behaviors (Parasuraman et al., 1994).

\section{Research methodology}

\subsection{Research design}

Following Parasuraman et al. (1994), the research structure consists of two stages as below:

\section{Stage 1:}

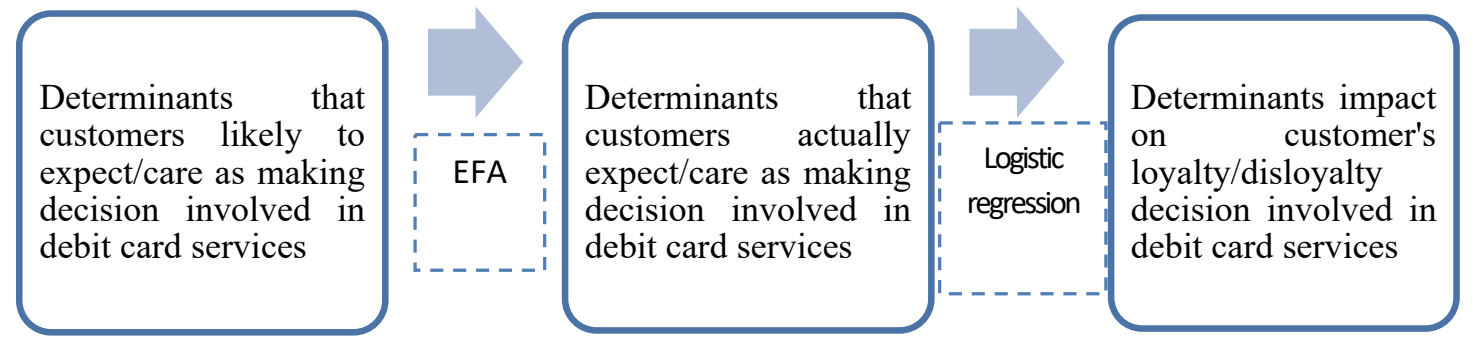

\section{Stage 2:}

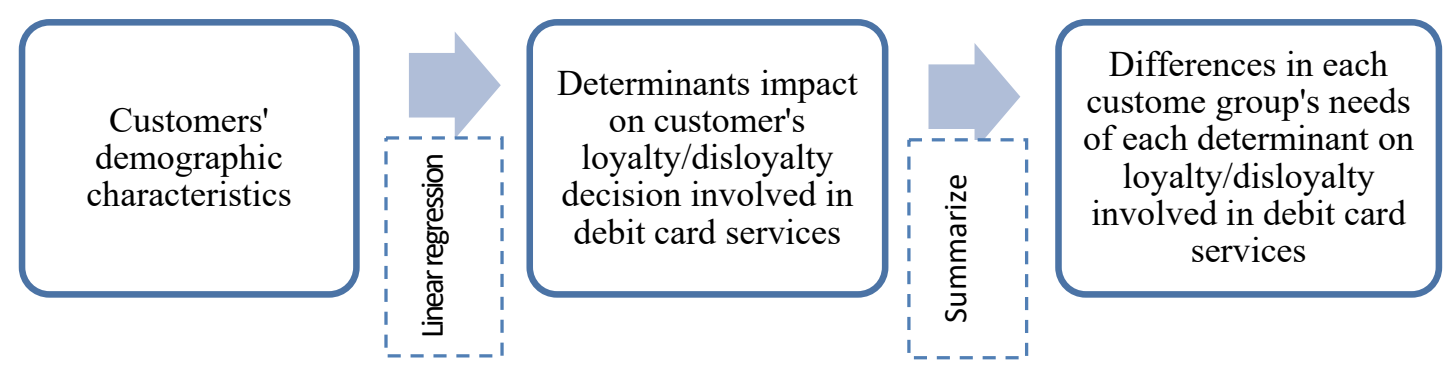

Note: This exhibit indicates steps to solve research questions

Fig. 1. Research Structure

In stage 1, we identify customer expectations and determinants of customer satisfaction in debit card services provided by CBs. According to SERVQUAL model raised by Parasuraman et al. $(1985,1988)$, determinants that customers are likely to expect or care are chosen and then modified due to approach of Fornell (1992). Thus, determinants that are initially considered to make debit card holding decision consist of Service features, Price, Brand Image and Interaction. Each factor is selected from previous researches. Al-Eisa and Alhemoud (2009), Jamal and Naser (2002) highlight that customers care for procedures (referred to as progression of service delivery), time of service delivery, product diversification, the distance between service providers and customers and service price. Matzler et al. (2006), Varki and Colgate (2001), Seyedaliakbara et al. (2016) illustrate the vital effect of price on 
customer perceptions. Levesque et al. (1996) divide prices of banking service into three categories such as nominal interest rate written on the contract, negotiated interest rate except from nominal interest rate or fees and penalty interest rate as breaching the agreement. Besides, firm's brand image was found to directly influence service quality according to customers (Nguyen \& LeBlanc, 1998). Bank's brand image that is widely known and loved is likely to positively affect customer perceptions toward its services (Che-Ha \& Hashim, 2007). Last but not least, the fourth factor is the interaction between bank officers and its customers, which represents equipment and facilities (Barber \& Scarcelli, 2010), the appearance of officers (Reimer \& Kuehn, 2005), attitude and advisory capacity (Jamal \& Naser, 2002). After providing services, customer care services such as expressing bank's deep gratitude to existing customers, sending emails to customers regularly with useful information, etc. are proved to promote customer sympathy (Ennew \& Binks, 1999).

In stage 2, data of customer demographics (expressed on the top of the questionnaire) is coded. Then, we use a linear regression model to analyze the relationship between the mentioned coded demographic variables and significant determinants found in the first stage to examine the differences between each customer group's need and each feature involved in loyalty or disloyalty decision in debit card services. The purpose of this stage is to learn more about different groups of customers, then recognize the target customer group and propose appropriate plans to take care of them (Şchiopu, 2010; Nguyen, 2019). Many demographic variables such as gender, age, education level, marital status, income were showed the impact on customer behavior (Farokhi et al., 2016; Negeri, 2017).

\subsection{Research sample}

This paper uses a random sample encompassing 428 customers whose debit cards are issued by CBs located in Hanoi, Vietnam. This sample size is adequate for conducting EFA and multiple regression (Tabachnick \& Fidell, 2007).

457 written survey questionnaires for gathering information were filled out directly by customers over the period from December 2016 to June 2017. There were 428 responses meeting the requirement. The survey questionnaire included 3 main parts: (i) customer information, (ii) Assessment the level of importance of 23 determinants in making decision of using debit cards and (iii) customer's future decision of using debit cards. The second part uses the Likert scale with five-point scale that allows the respondents to express how important they assess each factor.

\subsection{Processing techniques}

We analyze data through the descriptive statistics, exploratory factor analysis (EFA), and binary logistic regression with SPSS 22. This study employs the Kaiser - Meyer - Olkin, the Bartlett's test, the Total variance Explained, Loading Factor (in Rotated Component Matrix), and Cronbach Alpha to measure the adequacy and reliability of scales shown in Table 1. After that, we acquire FAC as independent variable in Logistic Regression.

The Binary Logistic Regression model is given as below:

$$
\log (p / 1-p)=\alpha+\beta_{1} X_{1}+\beta_{2} X_{2}+\ldots .+\beta_{n} X_{n}
$$

where: $p$ denotes the probability of the event that customers increase their frequency of using debit card. $\mathrm{X}_{1}, \mathrm{X}_{2} \ldots \mathrm{X}_{\mathrm{n}}$ represent FACs found after EFA. In order to assess the Logistic model fit, we test -2 Log likelihood indicator, sig. in Hosmer and Lemeshow Test. The Linear Regression model is given as below:

$$
Y_{i}=\alpha+\beta_{1} X_{1}+\beta_{2} X_{2}+\ldots .+\beta_{n} X_{n}+e_{i}
$$

where: $Y_{i}$ refers to as a significant $\mathrm{FAC}_{\mathrm{i}}$ found through Logistic model. $X_{1}, X_{2} \ldots X_{n}$ represent variables described in Table 2. $e_{i}$ refers to as a random error. In order to assess the model reliability, the value of $\mathrm{R}$ square and the value of Durbin Watson were used. 


\section{Variables}

Stage 1: The dependent variable is Loyalty that takes the value of 1 if customers increase their frequency of using debit card and 0 otherwise. The underlying factor includes 23 determinants that customers may appreciate as making debit card using decision.

\section{Table 1}

Underlying determinants in research model in stage 1

\begin{tabular}{|c|c|c|}
\hline Scales & Items & Definition \\
\hline \multirow{11}{*}{ Service features } & Products & The diversity of debit card products \\
\hline & Procedures & Procedures the customers have to fulfill to active debit card \\
\hline & Balance & Bank's requirement of minimum balance on debit card account \\
\hline & Process & The ease of payment transactions \\
\hline & Convenience & The varied convenience provided by bank \\
\hline & Money safety & The security of money on the account \\
\hline & Money availability & The availability of money in the ATM \\
\hline & Privacy security & The security of card holder's personal information \\
\hline & Account security & The security of card holder's account \\
\hline & Network & The point - of - sale network \\
\hline & Promotion & The diversify and attraction of promotion programs \\
\hline \multirow{2}{*}{ Brand image } & Reputation & Bank has acquired high reputation \\
\hline & Fame & Many customers have known bank's brand image \\
\hline \multirow{3}{*}{ Price } & Opening fees & Banks charge fees to open card \\
\hline & Transaction fees & Banks charge fees to make transactions \\
\hline & Interest rate & Interest rate that card holder earns on deposit balance account \\
\hline \multirow{7}{*}{ Interaction } & Product advice & Bank officer's advice on using products \\
\hline & Opening card advice & Bank officer's advice and assistance on opening card \\
\hline & Attitude & Bank officer's attitude in solving card problems \\
\hline & Solving time & Time spent on solving card problems \\
\hline & Care & The bank's policy of caring customers \\
\hline & ATM & ATM appearance and position \\
\hline & Branches & Bank branch appearance and position \\
\hline
\end{tabular}

Note: This table describes underlying variables that are likely to be concerned by customers as they make debit card using decision. These variables were collected from previous researches.

Stage 2: The dependent variables are those correlated with Customer Loyalty explored in stage 1 . The independent variables stem from 17 demographic characteristics of customer, then form 44 dummy variables expressed as below:

\section{Table 2}

Demographic variables employed in stage 2

\begin{tabular}{|c|c|}
\hline Variables & Value \\
\hline Gender & Dummy $(D)=1$ if customers are male; $D=0$ if customers are female. \\
\hline Occupation & $\mathrm{D}=1$ if customers are students, running business, doing the housework, public servants; $\mathrm{D}=0$ otherwise. \\
\hline Income & $\mathrm{D}=1$ if monthly income stands "less than 5 million VND", "from 5 to less than 10 million VND"; $D=0$ otherwise \\
\hline Age & $\mathrm{D}=1$ if the age of customers is under 30 years old; $\mathrm{D}=0$ otherwise \\
\hline Education & $\mathrm{D}=1$ if customers hold a bachelor or master or doctoral degree; $\mathrm{D}=0$ otherwise \\
\hline Technology preference & $\mathrm{D}=1$ if "technology preference"; $\mathrm{D}=0$ if vice versa \\
\hline Bank & $\mathrm{D}=1$ if "BIDV"; "Vietinbank"; "Agribank"; "Vietcombank", "DongAbank"; $\mathrm{D}=0$ otherwise \\
\hline Time & $\mathrm{D}=1$ if "under 1 year", "from 1 to 3 years"; $\mathrm{D}=0$ otherwise \\
\hline Purpose & $\begin{array}{l}\mathrm{D}=1 \text { if "cash withdrawal", "pay for goods and services at stores", "online shopping", "check real time balance"; D } \\
=0 \text { otherwise }\end{array}$ \\
\hline Frequency & $\mathrm{D}=1$ if "pay for goods and services with card more than that in cash", $\mathrm{D}=0$ if vice versa \\
\hline Payment value & $\mathrm{D}=1$ if "the total payment value with card more than that in cash"; $\mathrm{D}=0$ if vice versa \\
\hline Card preference & $\mathrm{D}=1$ if "prefer card to cash"; $\mathrm{D}=0$ if vice versa \\
\hline Provider change & $\mathrm{D}=1$ if "readily change provider aiming at paying with card instead of paying in cash"; $\mathrm{D}=0$ if vice versa \\
\hline Reasons to choose bank & $\begin{array}{l}\mathrm{D}=1 \text { if "family members' bank", "good reputation", "spreading point of sale network", "efficient customer service", } \\
\text { "a wide variety of promotion programs", "competitive price policy"; } D=0 \text { otherwise }\end{array}$ \\
\hline Channels to know bank card & $\begin{array}{l}\mathrm{D}=1 \text { if "traditional mass media such as television, newspaper, etc.", "modern mass media such as social networks, } \\
\text { electronic media, etc.", "advertisement/leaflets", "acquaintances, friends", "being bank's existing customer"; } D=0\end{array}$ \\
\hline Viewpoint of card & $\begin{array}{l}\mathrm{D}=1 \text { if "safe place for money", "comfortable place for money", "easy for payments", "style of person having high } \\
\text { technology preference"; } D=0 \text { otherwise }\end{array}$ \\
\hline Awareness of card & $\mathrm{D}=1$ if card refers to as "level", "personality", "unimportance"; $\mathrm{D}=0$ otherwise \\
\hline
\end{tabular}




\section{Results and Discussion}

\subsection{Findings in stage 1}

Descriptive statistics

The descriptive statistics of the importance score of underlying determinants are shown in Table 3. Determinants which customers pay more attention than others carry the value of mean greater than 4.2 including Privacy Security, Account Security, Money Safety, and Money Availability. Due to the fact that account fraud has rapidly increased in recent years in both big and small Vietnamese banks, customers concern about the service security.

\section{Table 3}

Mean of underlying determinants

\begin{tabular}{|c|c|c|c|c|c|}
\hline Items & Mean & Variance & Items & Mean & Variance \\
\hline Product & 3.251 & 0.8884 & Reputation & 3.932 & 0.8378 \\
\hline Procedures & 3.557 & 0.8549 & Fame & 3.756 & 0.7942 \\
\hline Balance & 3.405 & 0.8033 & Opening fees & 3.782 & 0.8541 \\
\hline Process & 3.822 & 0.7544 & Transaction fees & 3.956 & 0.9040 \\
\hline Convenience & 3.913 & 0.8219 & Interest rate & 3.679 & 0.9605 \\
\hline Money safety & 4.321 & 0.8434 & Product advice & 3.632 & 0.8437 \\
\hline Money availability & 4.253 & 0.8916 & Opening card advice & 3.656 & 0.7878 \\
\hline Privacy security & 4.492 & 0.7853 & Attitude & 3.937 & 0.7526 \\
\hline Account security & 4.525 & 0.7545 & Problem solving time & 4.061 & 0.7544 \\
\hline Network & 4.143 & 0.7604 & Care & 3.803 & 0.7498 \\
\hline \multirow[t]{2}{*}{ Promotion } & 3.426 & 0.8370 & ATM & 3.698 & 0.7752 \\
\hline & & & Branches & 3.604 & 0.7723 \\
\hline
\end{tabular}

Note: This table expresses the descriptive statistics of each question in the questionnaire. Due to 5 - point Likert scale, the value of mean in 2.61 - 3.4 represents the respondents do not reveal their opinions about issue received (also called neutral). The value in 4.21-5 represents the maximum respect (strongly important).

\section{Validity and reliability tests of scales}

Conducting EFA of 23 items projected respected by customers as making debit card using decision, we found out that sample sufficiency index KMO is 0.838 (greater than 0.5). Sig. value in Bartlett test is 0.000 (smaller than 0.05) for Approx. Consequently, factor analysis is reasonable and variables are correlated in the overall (shown in Appendix No. 1).

Total variance explained is $65.845 \%$ (greater than $50 \%$ ), which indicates that the new five determinants together account for $65.845 \%$ of the total variance. The result from the matrix of the rotated factor loadings shows that 22 items of 23 original items are grouped into new 5 groups and all items having factor loadings greater than 0.5 . This ensures that these items are practical significance (see Appendix No. 1). The "Promotion" item is removed because its factor loading is below 0.5 , which is consistent with the context of Vietnam. Debit card promotions that have been conducted by Vietnamese banks mainly focus on paying no fee as open card firstly and receiving discount rates for taking card payments. The popularity of the free charge for first time users makes this benefit to be considered customer's apparent right. Many of discount promotions are thanks to with the partnership between card providers and businesses such as shops, restaurants, hotels, beauty salons, resorts, etc. Cardholders also receive many types of vouchers in the events of bank's birthday, customer's birthday, opening ceremony, etc. Cardholders only get this benefit in the case of they buy other goods or services supplied by bank's partners in the alliance. Thus, this promotion program sometimes is not attractive to customers. Hence, they might not consider Promotion item as important item when they make decision to hold debit card.

Looking at the table labeled Rotated Component Matrix, from 23 underlying items, after deleting Promotion item, the rest of 22 items is grouped into 5 categories (named FAC 1, FAC 2, FAC 3, FAC 4 and FAC 5 respectively). For a measure of scale reliability with Cronbach's alpha for 5 above FAC, the results are 0,$875 ; 0,866 ; 0,732 ; 0,645$ and 0,823 respectively (see Appendix No. 1). Having alpha coefficient below 0.7, FAC 4, composed of Products, Balance and Procedures, is unacceptable (Kline, 
1998). This finding is consistent with the context of Vietnam. According to our previous research, debit cardholders recently have generally accepted Vietnamese banks' regulation of the minimum balances in the deposit account, steps need to complete for holding card and the diversify of card products. Cardholders score these items at 3.44; 3.56 and 3.37 respectively (Truong \& Phan, 2017). The relative similarly in those items among Vietnamese banks results in having no impact on provider choice of customers. After EFA, there are 19 determinants (in 4 groups) showing that cardholders pay attention to as making debit card using decision (shown in Table 4).

Table 4

Lists of determinants that cardholders pay attention to as making decisions on using debit cards offered by banks

\begin{tabular}{|c|c|c|c|c|c|}
\hline $\begin{array}{l}\text { Factor } \\
\text { groups }\end{array}$ & Items & $\begin{array}{l}\text { Factor } \\
\text { loading }\end{array}$ & $\begin{array}{l}\text { Factor } \\
\text { groups }\end{array}$ & Items & Factor loading \\
\hline \multirow{7}{*}{ FAC 1} & Opening card advice & 0.870 & \multirow{7}{*}{ FAC 2} & Money safety & 0.852 \\
\hline & Attitude & 0.861 & & Privacy security & 0.849 \\
\hline & Care & 0.810 & & Account security & 0.822 \\
\hline & Product advice & 0.806 & & Money availability & 0.693 \\
\hline & Problem solving time & 0.801 & & Process & 0.610 \\
\hline & ATM & 0.677 & & Network & 0.598 \\
\hline & Branches & 0.650 & & Convenience & 0.592 \\
\hline \multirow{3}{*}{ FAC 3} & Fame & 0.824 & \multirow{3}{*}{ FAC 5} & Transaction fees & 0.784 \\
\hline & \multirow[t]{2}{*}{ Reputation } & \multirow[t]{2}{*}{0.800} & & Interest rate & 0.746 \\
\hline & & & & Opening fees & 0.511 \\
\hline
\end{tabular}

Note: This table summarizes factor groups that have influence customer's decision on making payments by debit cards after EFA and conducting the validity and reliability tests of scales.

\section{Results from Logistic regression analysis}

Applying Logistic regression technique to 4 factor groups found above and Overall Customer Loyalty, the value of -2 Log likelihood is 270.200 indicating the close relation among variables in the model. The value of sig. in Hosmer and Lemeshow Test is $0.007(<0.05)$ showing the model fit well the data (see in Appendix No. 2). Table 5 shows the Logistic regression results.

\section{Table 5}

The relationship between Determinants Groups and Customer Loyalty Involved in Using Debit Cards

\begin{tabular}{cc}
\hline Independent variables & Estimates \\
\hline FAC 1 & 0.173 \\
& $(0.167)$ \\
FAC 2 & 0.432 \\
& $(0.137)^{* * *}$ \\
FAC 3 & 0.055 \\
& $(0.168)$ \\
FAC 5 & 0.536 \\
& $(0.174)^{* * *}$ \\
Constant & 2.310 \\
\end{tabular}

Standard errors are in parentheses.

Dependent variable is Overall Customer Loyalty.

Number of observations: 428

$* * *, * *$ and $*$ indicate significance at $1 \%, 5 \%$, and $10 \%$ level respectively.

Note: This table shows the estimates of independent variables in the model.

This finding of the correlation analysis shows positive and significant relationships between two factor groups (FAC 2 and FAC 5) and the Overall Customer Loyalty. This implies that customers who regard the Service Features and Price as the important matters are more likely to repeat patronage in the case of holding debit card. This outcome is in line with the fact in Vietnam. Cardholders in Vietnam expect 
debit cards to have many of similar features to cash such as the convenience in making payments for goods and services (representing the availability of cash in ATM, the spreading of payment points and the easiness in payment processing). Also, customers reveal their expectation of using debit card make them avoid many limitations of holding cash (such as easily acquiring counterfeit money, being lost or stolen, inconvenience and lack of security as holding a large amount of money, etc.). Besides, card holders desire to earn interest rate on account balance greater than transaction fees paid to banks. Because customers pay attention to service features and price as deciding whether they should continue to use debit cards or not, it is necessary for Vietnamese banks to improve their service features and price policies in order to meet customer needs as well bank's profitability expectation.

\subsection{Findings in stage 2}

In this stage, we examine the impact of demographic variables on factor groups having significant correlation with the Overall customer Loyalty (named FAC 2 and FAC 5 found in stage 1). Running the linear regression to check the relationship between Independent variables in Table 1 and FAC 2, the results are expressed in Table 6. The adjusted $\mathrm{R}-$ Squared is $31.9 \%$ showing that independent variables explain $32.9 \%$ the variation of the dependent variable. The Durbin Watson test statistic value is 1.706 (lies between 1 and 3). Thus, there is no autocorrelation in the model (see Appendix No. 3).

\section{Table 6}

The impact of demographic variable on FAC 2

\begin{tabular}{lc}
\hline Independent variables & Estimates \\
\hline Male & $-0.073^{*}(0.085)$ \\
Being student & $-0.211^{* * *}(0.161)$ \\
Doing the housework & $-0.086^{* *}(0.333)$ \\
Being a public servant & $-0.192^{* * *}(0.091)$ \\
Under the age of 30 & $0.140^{* * *}(0.89)$ \\
Bachelor & $-0.093^{* *}(0.084)$ \\
Pay for goods and services at stores & $0.137^{* * *}(0.101)$ \\
Online shopping & $0.114^{* * *}(0.090)$ \\
Check real time balance & $0.200^{* * *}(0.098)$ \\
The total payment value with card more than in cash & $-0.157^{* * *}(0.101)$ \\
Spreading point of sale network & $0.128^{* * *}(0.097)$ \\
Efficient customer service & $0.203^{* * *}(0.094)$ \\
Modern mass media such as social network, e-media... & $-0.327^{* * *}(0.096)$ \\
Advertisement/leaflets & $-0.104^{* *}(0.123)$ \\
Being bank's existing customer & $-0.101^{* *}(0.093)$ \\
Safe place for money $i$. & $0.085^{* *}(0.088)$ \\
Style of person having high technology preference & $-0.087^{* *}(0.104)$ \\
Personality & $0.074^{*}(0.115)$ \\
Constant & $-0.198(0.153)$ \\
\hline \hline Note: This table indicates the correlation between demographic variables and FAC2. Standard errors are in parentheses. The number of observations is
\end{tabular}

Results in Table 6 show that there are 18 out of 44 demographic variables being correlated with FAC 2. For eight variables that are positively correlated with FAC 2, we note that a certain portion of customers have a higher demand for Service Features than others. They are under the age of 30, using debit cards to pay for goods and services in stores or online shopping, using debit card to check real time balance. For them, debit cards are considered to be safe to store money and express their personality. This cardholder group selects debit card providers because of the spreading point of sale network and efficient customer service. Thus, if a bank targets the customer segment with above characteristics, the bank should improve all items in FAC 2 in order to retain customer loyalty. For 10 variables having a negative correlation with $\mathrm{FAC} 2$, we find that a specific portion of customers requires less than others about Service Features. They are men, being students or doing housework or being public servants. Importantly, this group includes customers who graduated universities or colleges and having been paying for goods and services with debit cards greater than in cash. This consumer group gets to know about debit cards via e-media, social networks, advertisements or leaflets or through using other banking services. For them, bank card in general and debit cards in particular express the style of high-tech preference. Thus, if a bank targets the customer segment with these features, it should remain all items in FAC 2 as the present level and give priority to other sides of debit card services. To explain 
the relationship between Independent variables in Table 2 and FAC 5, we continued to run the linear regression, acquired results expressed in Table 7 . The adjusted $\mathrm{R}$-squared is $16.7 \%$ indicating that independent variables explain $16.7 \%$ the variation in the dependent variable. The Durbin Watson test statistic value is 2.101 (lies between 1 and 3). Thus, there is no autocorrelation in the model (see Appendix No. 4).

\section{Table 7}

The impact of demographic variables on FAC 5

\begin{tabular}{|c|c|}
\hline Independent variables & Estimates \\
\hline Running business & $-0.206^{* * *}(0.117)$ \\
\hline Being a public servant & $-0.146 * * *(0.110)$ \\
\hline Technology preference & $0.102 * *(0.135)$ \\
\hline Vietinbank & $-0.077 *(0.112)$ \\
\hline Pay for goods and services at stores & $0.167 * * *(0.106)$ \\
\hline Online shopping & $0.114 * *(0.101)$ \\
\hline Pay for goods and services with card more than that in cash & $0.137 * *(0.145)$ \\
\hline The total payment value with card more than in cash & $-0.167 * * *(0.145)$ \\
\hline Readily change provider aiming at paying with card instead of paying in cash & $-0.152 * * *(0.099)$ \\
\hline Good reputation & $-0.133 * * *(0.108)$ \\
\hline Efficient customer service & $0.206 * * *(0.101)$ \\
\hline Modern mass media such as social network, e-media... & $0.100 * *(0.095)$ \\
\hline Safe place for money & $-0.120 * *(0.095)$ \\
\hline Personality & $-0.095 * *(0.127)$ \\
\hline Constant & $-0.071(0.167)$ \\
\hline
\end{tabular}

The outcome, shown in Table 7, indicates the relationship between demographic variables and FAC 5. There are 14 out of 44 demographic variables having a correlation with FAC 5, including six positively correlated variables and eight negatively correlated variables. For six variables having positive correlation, we highlight that a specific portion of cardholders highly demand for Price more than others. This customer group consists of consumers who prefer high technology, get to know bank card through e-media, social networks. They use debit card for making payments at stores or e-shopping and also pay for goods and services with debit cards more than in cash. The reason for them to select card provider is good customer service. Thus, price policy is what banks need to concern about if they target to these consumer segments. For 8 variables having a negative correlation, these results indicate that a certain portion of customers pays less attention to Price than others. The common feature of this group is cardholders who are running businesses or public servants. They are Vietinbank's customers. They use debit cards for making payments with larger amount than paying in cash and thus they are willing to change card provider for paying with debit card if the current provider cannot meet their expectations. Due to their preference for payments in cards, they choose card providers with high reputation in the hope of acquiring a safe place for their money. This consumer group also desires bank card to show their personality. This outcome suggests that banks should keep their current price policy and give priority to other matters involved in debit card services if they are willing to offer debit card services to above customer group.

\section{Moreover, we add two important findings as below:}

Customers who are more interested in both Service Features and Price determinants than others (expressed by positively correlated with both FAC 2 and FAC 5) are cardholders using debit cards for making payments in stores or online shopping. This group also chooses debit card providers with good customer services. His customer segment would prefer and have a habit of making payments for goods and services by debit card through POS or carrying electronic transfers. In other words, they often use debit card for the purpose of payments rather than cash withdrawals. For countries like Vietnam that cardholders mainly have used their card for cash withdrawals (accounts for $86.6 \%$ of total cardholders according to report of Vietnam bank card Association in 2016), banks should explore and target this segment of customers in order to widen their customer base in line with increasing their revenues from debit card services. This segment of customer has high expectation on account security and privacy, payment process, advantages and POS networks involved in debit cards. Furthermore, this customer 
group also concerns about banks' price policy including interest rates on deposit accounts and fees paid for payment services more than others. They rarely or sometimes take money out of their demand account for using cash, so that they ask for earning proper interest rate on the account balance and being charged reasonable fees. The more customers make payments with debit cards, the better customer services they desire in the hope of being rapidly and efficiently solved all problems involved in debit cards transactions. To improve the convenience and security for all debit card services, it is inevitable for banks to customize services to meet the need of different customer groups with above characteristics. For price policy, it is difficult for banks to increase interest rates on demand deposit accounts for many reasons such as the right of depositors to withdraw cash or make payments as needed, the large amount of investment on maintaining and upgrading payment systems, etc. Thus, to attract the above customer segment, banks should strengthen their relationship with other goods and service providers in order to increase benefits for customers instead of the decline in fees and rise in interest rates.

On the other hand, there is a certain portion of customers who are less interested in Service Features and Price determinants than others (represents a negative correlation with both FAC 2 and FAC 5). They are public servants or consumers whose value paid by card is greater than paid in cash. According to the Directive No. 20/2007/CT-TTg on the increase in noncash payment signed by the Vietnam's Prime Minister in 2007, staffs who work in state agencies have to register to receive salaries and wages via their bank accounts from the date $1 / 1 / 2008$. Thus, up to the beginning of 2017 , this customer group has experienced long time for finding and using bank cards. The rapid development in payment services especially in paying for utilities in combination with their lack of time spending for daily purchases make them get used to making payments by many of bank cards and easily compare services offered by different banks. Up to now, services involved in debit card provided by most of Vietnamese banks have been relatively even. Customers have already chosen suitable banks they expect to be served longlasting. Due to above explanation, the customer group has less concern about FAC 2 and FAC 5 because they deeply understand about services involved in debit cards issued by Vietnamese banks. Thus, if banks target this segment, they should keep their recent service features and price policy plus providing related or complementary products with debit card services (also called cross-selling) to existing cardholders.

In short, through applying EFA, Logistic regression and Linear regression techniques to a dataset of 428 cardholders in Hanoi, we found out that Service Features and Price affect the loyalty of customers holding debit cards offered by Vietnamese banks. Moreover, customers in different groups of demographic characteristics express different concerns about these two determinants. Clearly, cardholders who usually pay for goods and services at stores or online shopping, choose banks with good customer care reveal higher demand for these two determinants than others. Conversely, cardholders who are public servants or make payments with card greater than in cash in value reveal their less concern about these two determinants. These findings suggest banks should conduct different policies in line with each of customer group and based on their strategies.

\section{References}

Al-Eisa, A., \& Alhemound, A. (2009). Using a multiple attribute approach for measuring customer satisfaction with retail banking. International Journal of Banking Marketing, 27(4), 294-314.

Barber, N., \& Scarcelli, J. (2010). Enhancing the assessment of tangible service quality through the creation of a cleanliness measurement scale. Managing Service Quality: An International Journal, 20(1), 70-88.

Baskar, S., \& Ramesh, M. (2010). Linkage between online banking service quality and. Perpectives of innovations, economics and business, 6, 45-52.

Boeschoten, W. C. (1998). Cash management, payment patterns and the demand for money. De Economist, 146, 117-142.

Brown, S. W., \& Swartz, T. A. (1898). A gap analysis of professional service quality. The Journal of Marketing, 53(2), 92-98.

Che-Ha, N., \& Hashim, S. (2007). Brand equity, customer satisfaction and loyalty: Malaysian banking sector. International Review of Business Research Papers, 3(5), 123-133. 
Chu, T. K. (2014). Evaluate the customer satisfaction in service quality - The case in BIC, Haiduong branch. The Journal of Econimcs and Development, 206, 61 - 69.

Dick, A., \& Basu, K. (1994). Customer loyalty: Toward an integrated conceptual framework. Journal of the Academy of Marketing Science, 22(2), 99 - 113.

Ennew, C., \& Binks, M. (1999). Impact of participative service relationships on quality, satisfaction and retention: An exploratory study. Journal of Business Research, 46(2), 121-132.

Farokhi, S., Teimourpour, B., Shekarriz, F., \& Masoudi, M. (2016). A new application of clustering for segmentation of banks'e-payment services based on profitability. Uncertain Supply Chain Management, 4(1), 55-60.

Gounaris, S., \& Stathakopoulos, V. (2004). Antecedents and consequences of brand loyalty: an empirical study. The Journal of Brand management, 11(4), 283 - 306.

Gronroos, C. (1984). A service quality model and its marketing implications. European Journal of Marketing, $18(4), 36-44$.

Gronroos, C. (2001). The perceived service quality concept - a mistake? Managing Service Quality: An International Journal, 11(3), 150-152.

Humphrey, D., Pulley, L., \& Vesala, J. (1996). Cash, paper, and electronic payments: a cross-country analysis. The Journal of Money, credit, and banking, 28(2), 914-939.

Jamal, A. \& Naser, K. (2002). Customer satisfaction and retail banking: an assessment of some of the key antecedents of customer satisfaction in retail banking. International Journal of Bank Marketing, 20(4), 146160.

Lehtinen, U., \& Lehtinen, J. R. (1982). A study of quality dimensions. Service Management Institute, 5, 25-32.

Levesque, T., \& McDougall, G. H. (1996). Determinants of customer satisfaction in retail banking. International Journal of Bank Marketing, 14(7), 12-20.

Matzler, K., Wurtele, A., \& Renzl, B. (2006). Dimensions of Price Satisfaction: A study in the Retail Banking Industry. International Journal of Banking Marketing, 24(4), 216-231.

Nguyen, M. S. (2017). Income Diversification and Bank Efficiency in Vietnam. Journal of Economics and Development, 19(3), 52-67.

Nguyen, N. \& LeBlanc, G. (1998). The mediating role of corporate image on customers' retention decisions: an investigation in financial services. International Journal of Bank Marketing, 16(2), 52-65.

Nguyen, T. T. M. (2019). An investigation into the relationship between materialism and green purchase behavior in Vietnam and Taiwan. Journal of Economics and Development, 21(2), 247-258.

Negeri, M. (2018). Application of A Probit Model in Assessing Determinants of Formal Financial Saving Behavior of Rural Households: The Case of Sinana District, Ethiopia. Journal of Economics and Development, 20(2), 94-106.

Oliver, R. L. (1980). A cognitive model of the antecedents and consequences of satisfaction decisions. The Journal of Marketing research, 17, 460 - 469.

Parasuraman, A., Zeithaml, V. A., \& Berry, L. L. (1985). A conceptual model of service quality and its implication. The Journal of Marketing, 49, 41 - 50.

Parasuraman, A., Zeithaml, V. A., \& Berry, L. L. (1994). Reassessment of expectation as a comparison standards in measuring service quality: implications for further research. The Journal of Marketing, 58(2), 111 - 124.

Parasuraman, A., Zeithmal, V. A., \& Berry, L. L. (1988). SERQUAL: a multi-item scale for measuring consumer perceptions of the service quality. The Journal of Retaitling, 64, 12 - 40.

Reimer, A., \& Kuehn, R. (2005). The impact of servicescape on quality perception. European Journal of Marketing, 39(7/8), 785-808.

Şchiopu, D. (2010). Applying twostep cluster analysis for identifying bank customers' profile. Buletinul, 62, 6675.

Seyedaliakbara, S. M., Zaripourb, M., Zangenehc, G. K., \& Sadeghid, H. (2016). An investigation into the determinants of customer satisfaction. Uncertain Supply Chain Management, 4, 263-268.

Teas, R. K. (1993). Consumer Expectations and the Measurement of Perceived Service Quality. The Journal of Professional Services Marketing, 8(2), 33-54.

Tran, Đ. T., \& Pham, L. (2013). The relationship between electronic banking and customer satisfaction, loyalty in Vietnam. The Journal of Economics and Development, 195, 26 - 33.

Tran, V. T., \& Bui, N. N. (2013). Research on customer satisfaction on lending service offered by Vietinbank, Vinh Long and Can Tho branches. The Journal of Development and Integration, 13(13), 59 - 64.

Truong, T. H., \& Phan, H. M. (2017). Assessing Vietnamese banking service quality based on customer satisfaction - Illustrating with debit card service. Business and Management: Framin compliance and dynamics (pp. 517-527). Ha Noi, Viet Nam: The National Economics University Publisher. 
Varki, S., \& Colgate, M. (2001). The role of price perceptions in an integrated model of behavioral intentions. Journal of Service Research, 3(3), 232-240.

Zeithaml, V. A., \& Bitner, M. J. (2000). Services marketing: Integrating customer focus across the firm. New York: Irwin McGraw-Hill.

\section{Appendix No. 1: Validity and reliability tests of scales in stage 1}

KMO and Bartlett's test in stage 1

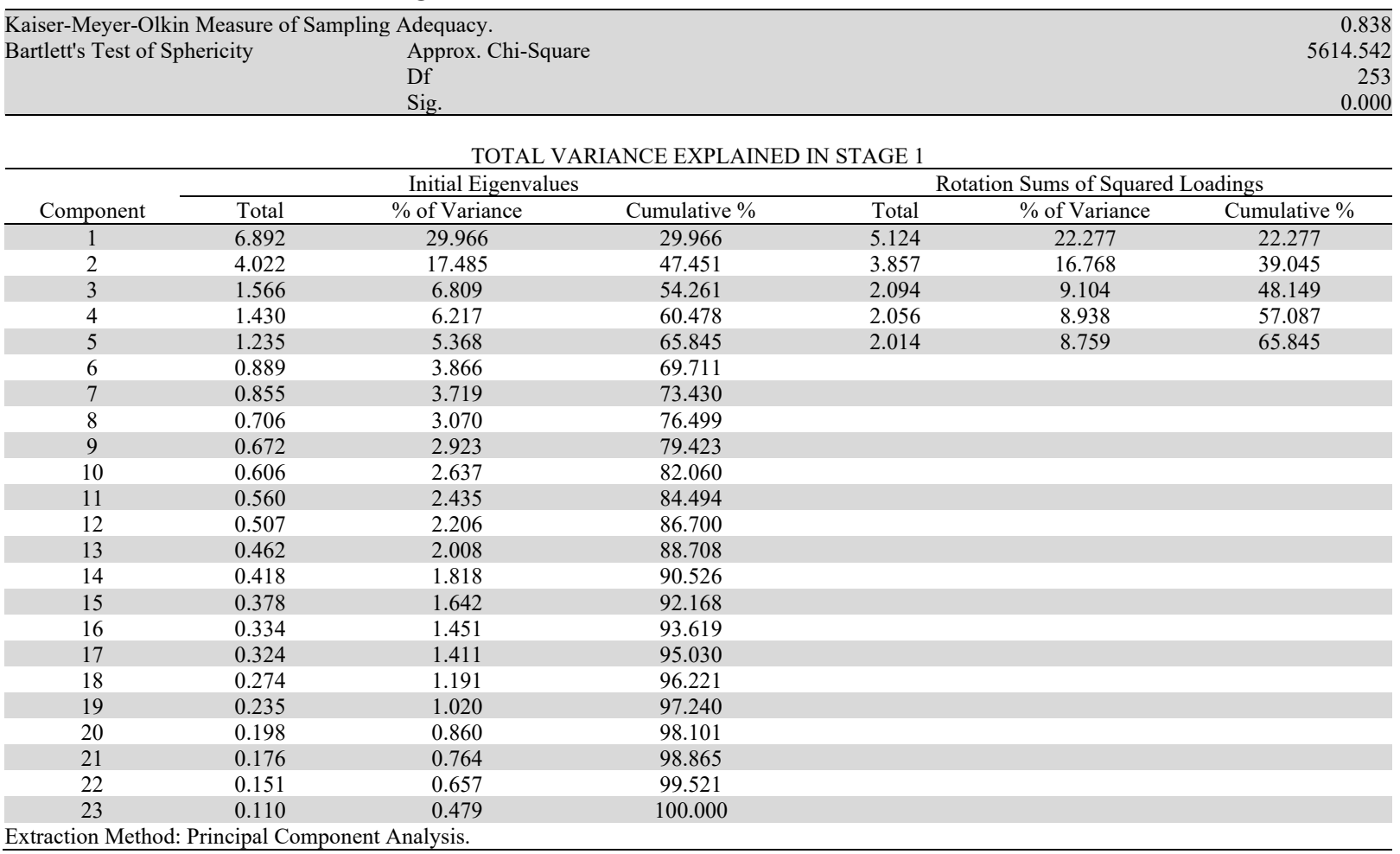

\section{ROTATED COMPONENT MATRIX IN STAGE 1}

\begin{tabular}{|c|c|c|c|c|c|}
\hline & \multicolumn{5}{|c|}{ Component } \\
\hline & 1 & 2 & 3 & 4 & 5 \\
\hline Opening card advice & 0.870 & & & & \\
\hline Attitude & 0.861 & & & & \\
\hline Care & 0.810 & & & & \\
\hline Product advice & 0.806 & & & & \\
\hline Problem solving time & 0.801 & & & & \\
\hline ATM & 0.677 & & & & \\
\hline Branches & 0.650 & & & & \\
\hline Money safety & & 0.852 & & & \\
\hline Privacy security & & 0.849 & & & \\
\hline Account security & & 0.822 & & & \\
\hline Money availability & & 0.693 & & & \\
\hline Process & & 0.610 & & & \\
\hline Network & & 0.598 & & & \\
\hline Conveniences & & 0.592 & & & \\
\hline Fame & & & 0.824 & & \\
\hline Reputation & & & 0.800 & & \\
\hline Transaction fees & & & & 0.784 & \\
\hline Interest rate & & & & 0.746 & \\
\hline Opening fees & & & & 0.511 & \\
\hline \multicolumn{6}{|l|}{ Promotion } \\
\hline Balance & & & & & 0.767 \\
\hline Procedures & & & & & 0.698 \\
\hline Products & & & & & 0.685 \\
\hline
\end{tabular}


RELIABILITY STATISTICS FOR FAC 1 IN STAGE 1

\begin{tabular}{|c|c|c|}
\hline Cronbach's Alpha & Cronbach's Alpha Based on Standardized Items & $\mathrm{N}$ of Items \\
\hline 0.875 & 0.875 & 7 \\
\hline \multicolumn{3}{|c|}{ RELIABILITY STATISTICS FOR FAC 2 IN STAGE 1} \\
\hline Cronbach's Alpha & Cronbach's Alpha Based on Standardized Items & $\mathrm{N}$ of Items \\
\hline 0.866 & 0.868 & 7 \\
\hline \multicolumn{3}{|c|}{ RELIABILITY STATISTICS FOR FAC 3 IN STAGE 1} \\
\hline Cronbach's Alpha & Cronbach's Alpha Based on Standardized Items & $\mathrm{N}$ of Items \\
\hline 0.732 & 0.733 & 2 \\
\hline \multicolumn{3}{|c|}{ RELIABILITY STATISTICS FOR FAC 4 IN STAGE 1} \\
\hline Cronbach's Alpha & Cronbach's Alpha Based on Standardized Items & $\mathrm{N}$ of Items \\
\hline 0.645 & 0.644 & 3 \\
\hline \multicolumn{3}{|c|}{ RELIABILITY STATISTICS FOR FAC 5 IN STAGE 1} \\
\hline Cronbach's Alpha & Cronbach's Alpha Based on Standardized Items & $\mathrm{N}$ of Items \\
\hline 0.823 & 0.825 & 3 \\
\hline
\end{tabular}

\section{Appendix No. 2}

Validity and reliability tests of logistic model in stage 1

\begin{tabular}{|c|c|c|c|}
\hline Step & -2 Log likelihood & Cox \& Snell R Square & Nagelkerke R Square \\
\hline 1 & $270.200^{\mathrm{a}}$ & 0.049 & 0.100 \\
\hline \multicolumn{4}{|c|}{$\begin{array}{c}\text { a. Estimation terminated at iteration number } 5 \text { because parameter estimates changed by less than } 0.001 \\
\text { HOSMER AND LEMESHOW TEST }\end{array}$} \\
\hline Step & Chi-square & df & Sig. \\
\hline 1 & 21.093 & 8 & 0.007 \\
\hline
\end{tabular}

\section{Appendix No. 3}

\section{Validity and reliability tests of linear regression}

Model examined the impact of demographic variables on FAC 2

\begin{tabular}{|c|c|c|c|c|c|c|c|c|c|c|}
\hline \multirow[b]{3}{*}{ Model } & \multicolumn{9}{|c|}{ MODEL SUMMARY } & \multirow[b]{3}{*}{$\begin{array}{l}\text { Durbin- } \\
\text { Watson }\end{array}$} \\
\hline & & & \multirow[b]{2}{*}{$\begin{array}{c}\text { Adjusted R } \\
\text { Square }\end{array}$} & \multirow[b]{2}{*}{$\begin{array}{l}\text { Std. Error of the } \\
\text { Estimate }\end{array}$} & \multicolumn{5}{|c|}{ Change Statistics } & \\
\hline & $\mathbf{R}$ & R Square & & & $\begin{array}{c}\text { R Square } \\
\text { Change }\end{array}$ & F Change & df1 & df2 & Sig. F Change & \\
\hline 1 & 0.612 & 0.375 & 0.292 & 0.84061009 & 0.375 & 4.517 & 50 & 377 & 0.000 & \\
\hline 2 & 0.612 & 0.375 & 0.294 & 0.83949774 & 0.000 & 0.000 & 1 & 377 & 0.987 & \\
\hline 3 & 0.612 & 0.375 & 0.295 & 0.83839003 & 0.000 & 0.000 & 1 & 378 & 0.983 & \\
\hline 4 & 0.612 & 0.375 & 0.297 & 0.83728715 & 0.000 & 0.001 & 1 & 379 & 0.976 & \\
\hline 5 & 0.612 & 0.375 & 0.299 & 0.83618860 & 0.000 & 0.001 & 1 & 380 & 0.976 & \\
\hline 6 & 0.612 & 0.375 & 0.301 & 0.83510001 & 0.000 & 0.006 & 1 & 381 & 0.938 & \\
\hline 7 & 0.612 & 0.375 & 0.303 & 0.83402208 & 0.000 & 0.012 & 1 & 382 & 0.913 & \\
\hline 8 & 0.612 & 0.375 & 0.305 & 0.83295293 & 0.000 & 0.016 & 1 & 383 & 0.899 & \\
\hline 9 & 0.612 & 0.375 & 0.306 & 0.83190217 & 0.000 & 0.029 & 1 & 384 & 0.864 & \\
\hline 10 & 0.612 & 0.374 & 0.308 & 0.83086946 & 0.000 & 0.042 & 1 & 385 & 0.837 & \\
\hline 11 & 0.612 & 0.374 & 0.310 & 0.82996259 & 0.000 & 0.156 & 1 & 386 & 0.693 & \\
\hline 12 & 0.611 & 0.374 & 0.311 & 0.82909808 & 0.000 & 0.192 & 1 & 387 & 0.661 & \\
\hline 13 & 0.611 & 0.374 & 0.312 & 0.82821594 & 0.000 & 0.173 & 1 & 388 & 0.678 & \\
\hline 14 & 0.611 & 0.373 & 0.314 & 0.82745627 & 0.000 & 0.285 & 1 & 389 & 0.594 & \\
\hline 15 & 0.611 & 0.373 & 0.315 & 0.82666135 & 0.000 & 0.249 & 1 & 390 & 0.618 & \\
\hline 16 & 0.610 & 0.372 & 0.316 & 0.82589834 & 0.000 & 0.277 & 1 & 391 & 0.599 & \\
\hline 17 & 0.610 & 0.372 & 0.318 & 0.82510766 & 0.000 & 0.248 & 1 & 392 & 0.619 & \\
\hline 18 & 0.609 & 0.371 & 0.319 & 0.82436345 & 0.000 & 0.290 & 1 & 393 & 0.591 & \\
\hline 19 & 0.609 & 0.371 & 0.320 & 0.82379009 & -0.001 & 0.451 & 1 & 394 & 0.502 & \\
\hline 20 & 0.608 & 0.370 & 0.321 & 0.82328499 & -0.001 & 0.515 & 1 & 395 & 0.474 & \\
\hline 21 & 0.607 & 0.369 & 0.321 & 0.82284153 & -0.001 & 0.572 & 1 & 396 & 0.450 & \\
\hline 22 & 0.607 & 0.368 & 0.322 & 0.82242110 & -0.001 & 0.593 & 1 & 397 & 0.442 & \\
\hline 23 & 0.606 & 0.367 & 0.323 & 0.82202507 & -0.001 & 0.616 & 1 & 398 & 0.433 & \\
\hline 24 & 0.605 & 0.366 & 0.324 & 0.82153037 & -0.001 & 0.519 & 1 & 399 & 0.472 & \\
\hline 25 & 0.604 & 0.365 & 0.324 & 0.82143639 & -0.001 & 0.908 & 1 & 400 & 0.341 & \\
\hline 26 & 0.603 & 0.363 & 0.323 & 0.82156820 & -0.002 & 1.129 & 1 & 401 & 0.289 & \\
\hline 27 & 0.601 & 0.361 & 0.323 & 0.82178734 & -0.002 & 1.215 & 1 & 402 & 0.271 & \\
\hline 28 & 0.599 & 0.359 & 0.323 & 0.82192816 & -0.002 & 1.138 & 1 & 403 & 0.287 & \\
\hline 29 & 0.598 & 0.357 & 0.322 & 0.82227915 & -0.002 & 1.346 & 1 & 404 & 0.247 & \\
\hline 30 & 0.595 & 0.354 & 0.321 & 0.82314359 & -0.003 & 1.854 & 1 & 405 & 0.174 & \\
\hline 31 & 0.592 & 0.351 & 0.319 & 0.82423675 & -0.003 & 2.082 & 1 & 406 & 0.150 & 1.706 \\
\hline
\end{tabular}


Appendix No. 4: Validity and reliability tests of linear regression

Model examined the impact of demographic variables on FAC 5

\begin{tabular}{|c|c|c|c|c|c|c|c|c|c|c|}
\hline \multirow[b]{2}{*}{ Model } & \multirow[b]{2}{*}{$\mathbf{R}$} & \multirow[b]{2}{*}{ R Square } & \multirow[b]{2}{*}{$\begin{array}{c}\text { Adjusted R } \\
\text { Square }\end{array}$} & \multirow[b]{2}{*}{$\begin{array}{l}\text { Std. Error of } \\
\text { the Estimate }\end{array}$} & \multicolumn{5}{|c|}{ Change Statistics } & \multirow[b]{2}{*}{$\begin{array}{l}\text { Durbin- } \\
\text { Watson }\end{array}$} \\
\hline & & & & & $\begin{array}{c}\text { R Square } \\
\text { Change }\end{array}$ & F Change & df1 & df2 & Sig. F Change & \\
\hline 1 & 0.501 & 0.251 & 0.152 & .92003466 & 0.251 & 2.525 & 50 & 377 & 0.000 & \\
\hline 2 & 0.501 & 0.251 & 0.154 & .91881849 & 0.000 & .001 & 1 & 377 & 0.971 & \\
\hline 3 & 0.501 & 0.251 & 0.156 & .91763156 & 0.000 & .021 & 1 & 378 & 0.884 & \\
\hline 4 & 0.501 & 0.251 & 0.158 & .91645690 & 0.000 & .028 & 1 & 379 & 0.868 & \\
\hline 5 & 0.501 & 0.251 & 0.160 & .91529909 & 0.000 & .038 & 1 & 380 & 0.846 & \\
\hline 6 & 0.501 & 0.251 & 0.162 & .91413916 & 0.000 & .032 & 1 & 381 & 0.857 & \\
\hline 7 & 0.501 & 0.251 & 0.164 & .91300166 & 0.000 & .047 & 1 & 382 & 0.828 & \\
\hline 8 & 0.500 & 0.250 & 0.167 & .91187557 & 0.000 & .053 & 1 & 383 & 0.817 & \\
\hline 9 & 0.500 & 0.250 & 0.169 & .91078379 & 0.000 & .079 & 1 & 384 & 0.779 & \\
\hline 10 & 0.500 & 0.250 & 0.170 & .90975459 & 0.000 & .128 & 1 & 385 & 0.721 & \\
\hline 11 & 0.500 & 0.250 & 0.172 & .90874875 & 0.000 & .145 & 1 & 386 & 0.704 & \\
\hline 12 & 0.499 & 0.249 & 0.174 & .90788040 & -0.001 & .259 & 1 & 387 & 0.611 & \\
\hline 13 & 0.499 & 0.249 & 0.175 & .90707743 & -0.001 & .312 & 1 & 388 & 0.577 & \\
\hline 14 & 0.498 & 0.248 & 0.177 & .90624867 & -0.001 & .288 & 1 & 389 & 0.592 & \\
\hline 15 & 0.497 & 0.247 & 0.178 & .90552530 & -0.001 & .376 & 1 & 390 & 0.540 & \\
\hline 16 & 0.497 & 0.247 & 0.179 & .90479237 & -0.001 & .366 & 1 & 391 & 0.546 & \\
\hline 17 & 0.496 & 0.246 & 0.181 & .90403473 & -0.001 & .342 & 1 & 392 & 0.559 & \\
\hline 18 & 0.495 & 0.245 & 0.182 & .90331321 & -0.001 & .371 & 1 & 393 & 0.543 & \\
\hline 19 & 0.494 & 0.244 & 0.183 & .90288275 & -0.001 & .624 & 1 & 394 & 0.430 & \\
\hline 20 & 0.493 & 0.243 & 0.184 & .90247591 & -0.001 & .643 & 1 & 395 & 0.423 & \\
\hline 21 & 0.492 & 0.242 & 0.184 & .90200815 & -0.001 & .589 & 1 & 396 & 0.443 & \\
\hline 22 & 0.490 & 0.240 & 0.185 & .90177236 & -0.002 & .792 & 1 & 397 & 0.374 & \\
\hline 23 & 0.488 & 0.239 & 0.185 & .90166672 & -0.002 & .907 & 1 & 398 & 0.342 & \\
\hline 24 & 0.486 & 0.236 & 0.185 & .90185708 & -0.002 & 1.169 & 1 & 399 & 0.280 & \\
\hline 25 & 0.484 & 0.234 & 0.185 & .90196593 & -0.002 & 1.097 & 1 & 400 & 0.296 & \\
\hline 26 & 0.482 & 0.232 & 0.184 & .90214296 & -0.002 & 1.158 & 1 & 401 & 0.283 & \\
\hline 27 & 0.479 & 0.229 & 0.183 & .90266320 & -0.003 & 1.465 & 1 & 402 & 0.227 & \\
\hline 28 & 0.476 & 0.227 & 0.183 & .90302404 & -0.003 & 1.323 & 1 & 403 & 0.251 & \\
\hline 29 & 0.473 & 0.224 & 0.182 & .90335173 & -0.002 & 1.294 & 1 & 404 & 0.256 & \\
\hline 30 & 0.469 & 0.220 & 0.180 & .90449832 & -0.004 & 2.031 & 1 & 405 & 0.155 & \\
\hline 31 & 0.465 & 0.216 & 0.178 & .90559381 & -0.004 & 1.986 & 1 & 406 & 0.159 & \\
\hline 32 & 0.462 & 0.213 & 0.177 & .90627099 & -0.003 & 1.610 & 1 & 407 & 0.205 & \\
\hline 33 & 0.457 & 0.209 & 0.174 & .90763923 & -0.004 & 2.236 & 1 & 408 & 0.136 & \\
\hline 34 & 0.452 & 0.205 & 0.172 & .90907750 & -0.004 & 2.300 & 1 & 409 & 0.130 & \\
\hline 35 & 0.448 & 0.201 & 0.170 & .91024846 & -0.004 & 2.059 & 1 & 410 & 0.152 & \\
\hline 36 & 0.443 & 0.197 & 0.167 & .91143537 & -0.004 & 2.075 & 1 & 411 & 0.150 & 2.101 \\
\hline
\end{tabular}

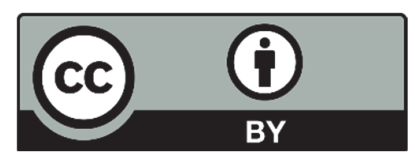

(C) 2020 by the authors; licensee Growing Science, Canada. This is an open access article distributed under the terms and conditions of the Creative Commons Attribution (CC-BY) license (http://creativecommons.org/licenses/by/4.0/). 